\title{
Perbandingan Hasil Belajar Model Pembelajaran Inquiry dengan Model Kooperatif Learning Tipe Number Head Together (NHT) dalam Mata Pelajaran (IPA) Kelas V SD Negeri 58 Kota Bengkulu
}

\author{
Asiyah $^{1}$, Ahmad Walid ${ }^{1}$, Adrian Topano ${ }^{1}$ \\ ${ }^{123}$ Program Studi Tadris IPA, IAIN Bengkulu. Bengkulu Indonesia \\ *Alamat Email Koresponden: adriantopan@ iainbengkulu.ac.id \\ diterima: 5 Agustus 2020, disetujui: 10 Agustus 2020, dipublikasikan: 30 September 2020
}

\begin{abstract}
This study aimed to determine whether the science learning outcomes of grade $V$ students who are taught using the NHT Model in SD Negeri 58 Bengkulu City. This study used two groups, namely class 5A with 31 people as the experimental group and class $5 B$ with 31 people as the control group. The research variable consisted of independent variables, namely the Inquiry learning model and the NHT model, while the dependent variable was the science learning outcome. Based on the results of the study, it was found that the posttest results of class $5 \mathrm{~A}$ students who used the Inquiry Learning Model, namely in the medium and high categories of $93 \%$ got a score of 60 to 100 while the learning outcomes of class $5 B$ using the NHT Model were $81 \%$ getting a score of 50 to 90 . shows that the science learning outcomes of grade V students who are taught using the Inquiry Learning Model are better than those using the NHT model in SD Negeri 58 Bengkulu City.
\end{abstract}

Keywords : Cooperative Learning, Number Head Together (NHT), Learning Outcomes, Inquiry Learning Model,

\section{PENDAHULUAN}

Dalam kamus Besar Bahasa Indonesia (KBBI), belajar memiliki arti "berusaha memperoleh kepandaian atau Ilmu (Anwar, 2016). Sebagaimana Allah SWT berfirman di dalam surah Thaha ayat 114 yang berbunyi :

Maka Maha Tinggi Allah raja yang sebenar-benarnya, dan janganlah kamu tergesa-gesa membaca Al-Qur'am sebelum disempurnakan mewahyukannya kepadamamu, dan katakanlah: "Ya Tuhanku, tambahkanlah kepadaku ilmu pengetahuan (Depag RI, 2020).

Dari ayat di atas sudah sepatutnya manusia harus terus menuntut ilmu karena ilmu merupakan suatu usaha manusia untuk memenuhi kebutuhanya mendapatkan ilmu atau kepandaian yang belum dipunyai sebelumnya. Belajar dimulai sejak manusia 78 lahir (Baharuddin dan Wahyuni 2018). Belajar dimaknai sebagai suatu proses untuk memperoleh motivasi dalam pengetahuan, keterampilan kebiasaan dan tingkah langku. Selain itu belajar sebagai suatu upaya memperoleh pengetahuan atau keterampilan melalui intruksi (Susanto, 2013). Instruksi yang dimaksud adalah arahan atau bimbingan dari pendidik atau guru. Proses belajar, perkembangan dan pendidikan merupakan suatu peristiwa dalam tindakan sehari-hari (Dimyanti dan Mudjiono, 2016). Pendidikan yang dimaksud disini adalah pandangan yang mendasari seluruh aktivitas pendidikan, baik dalam rangka penyusunan teori peranan maupun pelaksanaan, dan penyelenggaraan pendidikan, karena pendidikan adalah usaha sadar yang sistematik selalu bertolak dari sejumlah azas I/ljournal.univetbantara.ac.id/index.php/JBL/ 
tertentu. Landasan dan azas tersebut sangat penting, karena merupakan pilar untuk pengembangan manusia dan masyarakat suatu bangsa tertentu (Maunah, 2019).

Selain itu, belajar merupakan suatu upaya memperoleh melalui instruksi. Selanjutnya ada lima kategori yang dipelajari oleh manusia. Yaitu :

1. Keterampilan motoris, yaitu keterampilan yang diperlihatkan dari berbagai gerakan badan, misalnya menulis, menendang bola, bertepuk tangan, berlari dan loncat.

2. Informasi verbal, informasi ini sangat dipengaruhi oleh kemampuan otak siswa, misalnya seseorang dapat memahami sesuatu dengan berbicara, menulis, menggambar, dan lainnya berupa simbol yang tampak (verbal).

3. Kemampuan intelektual, selain menggunakan simbol verbal, manusia mampu melakukan interaksi dengan dunia luar melalui kemampuan intelektualnya, misalnya mampu membedakan warna, bentuk dan ukuran.

4. Strategi kognitif, organisasi keterampilan yang internal, yang sangat diperlukan untuk belajar mengingat dan berpikir. Kemampuan kognitif ini lebih ditunjukkan ke dunia luar, dan tidak dapat dipelajari dengan sekali saja memerlukan perbaikan dan latihan terus-menerus.

5. Sikap, sikap merupakan faktor penting dalam belajar karena tanpa kemampuan ini belajar takkan berhasil dengan baik. Sifat seseorang dalam belajar akan sangat mempengaruhi hasil yang diperoleh dari belajar tersebut. Sikap akan sangat tergantung pada pendirian, kepribadian dan keyakinannya, tidak dapat dipelajari atau dipaksakan, tetapi perlu kesadaran diri yang penuh (Susanto, 2013).
Oleh karena itu, pendidikan merupakan suatu hal dan unsur yang sangat penting didalam pembentukan sumber daya manusia yang cerdas, kreatif, inovatif dan berwawasan. Undang-undang RI Nomor 20 Tahun 2003 tentang Sistem Pendidikan Nasional mengharuskan pendidikan berakar pada kebudayaan nasional dan nilai-nilai agama yang berdasarkan pada pancasila dan Undang-Undang Dasar 1945. Sedangkan tenaga pendidikan adalah anggota masyarakat yang mengabdikan diri dalam penyelenggaraan pendidikan.

Menurut ayat ini yang berhak menjadi tenaga kependidikan adalah setiap anggota masyarakat yang mengabdikan dirinya dalam penyelenggaraan pendidikan (Pidarta, 2017). Oleh karena itu, tentulah tingkat pendidikan yang ada didalam suatu negara akan menunjukan kualitas dan tingkat kemajuan suatu negara tersebut. Berdasarkan observasi awal yang peneliti lakukan di SD Negeri 58 Kota Bengkulu pada tanggal 19 Februari 2020 di peroleh informasi bahwa rendahnya hasil belajar siswa terutama pelajaran IPA masih belum mencapai KKM yaitu 70 . Peneliti sudah melihat banyak usaha dari para guru dalam menerapakan berbagai model-model pembelajaran yang khususnya pada mata pelajaran Ilmu Pengetahuan Alam (IPA), seperti Contextual Teaching and learning yaitu model pembelajaran yang dimulai dengan dengan tanya jawab lisan yang terkait dengan dunia nyata siswa.

Dan beberapa model yang lain seperti Problem Based Learning untuk melatih dan mengembangkan kemampuan untuk menyelesaikan masalah dari kehidupan aktual siswa dan menyenangkan agar siswa dapat berpikir optimal (Ngalimun, 2012) dan juga penerapan metode Discovery Learning dapat meningkatkan hasil belajar siswa 
(Bektiningsih, 2020). Tetapi masih terdapat juga beberapa kendala, misalnya terkendala dengan buku, waktu, biaya, bahan dan alatalat praktik, beberapa peserta didik yang susah dikontrol sehingga para siswa merasa kesulitan untuk memahaminya dan karena hal ini juga akhirnya para peserta didik jadi merasa malas untuk memperhatikan lalu akhirnya mereka menjadi mengobrol dengan temannya atau asyik bermain dan sibuk sendiri.

Berdasarkan observasi awal, ketertarikan penerapan untuk mencoba menerapkan dua model pada kelas yang berbeda, sehingga dari situ kita dapat membandingkan yang mana model yang lebih efektif untuk diterapkan, yaitu model pembelajaran Inquiry karena model ini mengajarkan bagaimana seorang anak menyelasaikan pertanyaan, atau pemeriksaan, penyelidikan. Dan model pembelajaran Kooperatif Learning Tipe Number Head Together karena model ini bisa membantu anak mengembangkan kerja sama antar kelompok dan membangun kekompakkan. Dari penelitian ini juga nanti dapat dijadikan salah satu opsi oleh para guru dalam menerapkan model pembelajaran yang cocok untuk mata pelajaran Ilmu Pengetahuan Alam ini. Maka dari itu peneliti menjadi tertarik untuk mengupas secara lebih dalam untuk menerapkan kedua model pembelajaran ini pada siswa kelas $\mathrm{V}$ dengan memberikan judul penelitian: Perbandingan Hasil Belajar Model Pembelajaran Inquiry Dengan Model Pembelajaran Kooperatif Learning Tipe Number Head Together (NHT) Dalam Mata Pelajaran IPA Kelas V SD Negeri 58 Kota Bengkulu.

\section{METODE}

Jenis penelitian ini adalah penelitian lapangan dengan pendekatan quasi eksperimental yang mengungkap hubungan antara dua variabel atau lebih atau mencari pengaruh suatu variabel terhadap variabel lainnya.

Dalam penelitian ini, sampel dibagi menjadi dua kelompok eksperimen yang diberi perlakuan dengan model pembelajaran Inquiry dan Numbered Heads Together (NHT). Desain penelitian yang digunakan dalam penelitian ini adalah Nonequivalent control group posstest design.

Populasi dalam penelitian ini adalah seluruh siswa kelas V SD Negeri 58 Kota Bengkulu. Sedangkan sampel dalam penelitian ini adalah siswa kelas VA dan VB dengan jumlah siswa sebanyak 62 orang.

Teknik pengumpulan data menggunakan observasi, test dan dokumentasi. Instrumen yang digunakan dalam penelitian ini yaitu lembar pre-test dan post-test. Teknik analisis data menggunakan uji prasyarat yakni uji normalitas dan homogenitas, sedangkan uji hipotesis menggunakan rumus $t$ (test).

\section{HASIL DAN PEMBAHASAN}

1. Pelaksanaan Perlakuan

Pada penelitian ini penulis bertindak sebagai observer. Kegiatan yang dilakukan pada tahapan perencanaan penelitian ini yaitu menyiapkan silabus, Rencana Pelaksanaan Pembelajaran (RPP), membuat pedoman penilaian, menyiapkan materi yang sesuai dengan kompetensi yang akan diajarkan, membuat media pembelajaran dan lembar kerja siswa (LKS).

Pada penelitian quasi eksperimen ini digunakan pembelajaran dengan model pembelajaran Inquiry dan Numbered Heads Together (NHT) pada siswa kelas VA dan VB SD Negeri 58 Kota Bengkulu yang berjumlah 62 orang siswa yang dilaksanakan selama dua jam pelajaran dengan alokasi waktu 2 x 35 menit (90 menit). 


\section{Observasi}

Pada saat pemberian perlakuan (treatment) dengan menggunakan model pembelajaran Inquiry dan Numbered Heads Together (NHT) pada kelas VA dan VB peneliti melakukan pengamatan (observasi) tentang aktivitas guru dan aktivitas siswa selama proses pembelajaran berlangsung. Observasi ini bertujuan untuk mengetahui apakah pembelajaran sudah sesuai dengan langkah-langkah yang sudah direncanakan atau belum. Dalam penelitian ini, peneliti dibantu oleh guru kelas.

\section{Hasil Tes}

Bagian ini menguraikan dan menganalisis hasil nilai pre test dan post test. Soal pre test dan post test diberikan kepada siswa pada kelas A dengan menggunakan model pembelajaran inquiry dan kelas B dengan menggunakan model pembelajaran NHT. Instrumen soal pre test diberikan kepada siswa sebelum penelitian dilakukan, dan post test diberikan kepada siswa diakhir penelitian.

a. Deskripsi Hasil Nilai Pre test Kelas A dan Kelas B

Adapun hasil pre test terhadap hasil belajar IPA yang dilakukan sebagai berikut:

1. Kelas VA (Model Inquiry)

Tabel 4.6 Perhitungan Nilai Mean Pretest Siswa Kelas VA

\begin{tabular}{ccc}
\hline X & F & Fx \\
\hline 70 & 2 & 140 \\
65 & 1 & 65 \\
60 & 5 & 300 \\
55 & 7 & 385 \\
50 & 5 & 250 \\
45 & 2 & 90 \\
40 & 6 & 240 \\
35 & 2 & 70 \\
30 & 1 & 30 \\
Jumlah & 31 & 1570 \\
\hline
\end{tabular}

$$
\begin{aligned}
& \bar{X}=\frac{\sum F x}{N}=\frac{1570}{31}=50,6 \\
& \mathrm{SD}=\sqrt{\frac{\sum x^{2}}{N}}=\sqrt{\frac{3200}{31}}=\sqrt{103,2}=10,1
\end{aligned}
$$

Selanjutnya menetapkan kelompok atas, tengah, dan bawah dengan memasukkan kedalam rumus sebagai berikut:

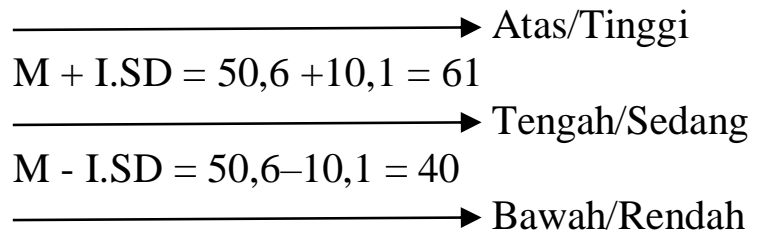

\begin{tabular}{|c|c|c|c|}
\hline \multicolumn{4}{|c|}{ VA } \\
\hline Nilai Pretest & Kategori & Frekuensi & $\%$ \\
\hline $61 \mathrm{ke}$ atas & $\begin{array}{l}\text { Atas / } \\
\text { Tinggi }\end{array}$ & 3 & $10 \%$ \\
\hline $60-40$ & $\begin{array}{l}\text { Tengah / } \\
\text { Sedang }\end{array}$ & 25 & $80 \%$ \\
\hline 39 ke bawah & $\begin{array}{l}\text { Bawah / } \\
\text { Rendah }\end{array}$ & 3 & $10 \%$ \\
\hline \multicolumn{2}{|c|}{ Jumlah } & 31 & $100 \%$ \\
\hline
\end{tabular}

Tabel 4.7 Frekuensi Hasil Pretest Siswa Kelas disimpulkan bahwapada kelas $5 \mathrm{~A}$, terdapat : 3 siswa dikelompok atas/tinggi (10\%), 25 siswa dikelompok tengah/sedang (80\%), dan 3 siswa dikelompok bawah/rendah (10\%).

2. Kelas VB (Model NHT)

Tabel 4.9 Perhitungan Nilai Mean Pretest Siswa Kelas VB

\begin{tabular}{ccc}
\hline $\mathbf{Y}$ & $\mathbf{F}$ & $\mathbf{F y}$ \\
\hline 65 & 1 & 65 \\
60 & 2 & 120 \\
55 & 5 & 275 \\
50 & 5 & 250 \\
45 & 5 & 225 \\
40 & 2 & 80 \\
35 & 5 & 175 \\
30 & 4 & 120 \\
25 & 2 & 50 \\
Jumlah & 31 & 1360 \\
\hline
\end{tabular}

journal homepage : http://journal.univetbantara.ac.id/index.php/JBL/ 


$$
\begin{aligned}
& \bar{X}=\frac{\sum F y}{N}=\frac{1360}{31}=43,8 \\
& \mathrm{SD}=\sqrt{\frac{\sum y^{2}}{N}}=\sqrt{\frac{3709}{31}}=\sqrt{119,6}=10,9
\end{aligned}
$$

Selanjutnya menetapkan kelompok atas, tengah, dan bawah dengan memasukkan kedalam rumus sebagai berikut:

$$
\begin{aligned}
& \longrightarrow \text { Atas/Tinggi } \\
& \mathrm{M}+\mathrm{I} . \mathrm{SD}=43,8+10,9=54 \\
& \longrightarrow \text { Tengah/Sedang } \\
& \mathrm{M}-\mathrm{I} . \mathrm{SD}=43,8-10,9=33
\end{aligned}
$$

Tabel 4.10 Frekuensi Hasil Pretest Siswa Kelas VB

\begin{tabular}{cccc}
\hline Nilai Pretest & Kategori & Frekuensi & $\%$ \\
\hline 54 ke atas & Atas / & 8 & 25,8 \\
& Tinggi & & $\%$ \\
$53-33$ & Tengah / & 17 & 54,8 \\
& Sedang & & $\%$ \\
32 ke bawah & Bawah / & 6 & 19,3 \\
& Rendah & & $\%$ \\
\hline \multicolumn{2}{c}{ Jumlah } & 31 & $100 \%$ \\
\hline
\end{tabular}

Dari analisis diatas, dapat disimpulkan bahwa pada kelas $5 \mathrm{~B}$, terdapat: 8 siswa dikelompok atas/tinggi (25,8\%), 17 siswa dikelompok tengah/sedang $(54,8 \%)$, dan 6 siswa dikelompok bawah/rendah $(19,3$ $\%)$.

Berdasarkan analisis pretest kedua kelas tersebut, untuk mengetahui apakah penelitian peneliti bisa dilanjutkan atau tidak. Maka dilakukan uji prasyarat yaitu uji normalitas dan uji homogenitas pretest.

\section{Analisis Data}

a. Uji Normalitas

Perhitungan uji normalitas dilakukan dengan cara membandingkan nilai $\mathrm{X}^{2}$ hitung dengan $\mathrm{X}_{\text {tabel }}^{2}$ pada taraf signifikansi d. $\mathrm{b}=\mathrm{k}$ -
$3=7-3=4=0,05$ didapat $X_{\text {tabel }}^{2}=9,488$ dengan kriteria pengujian sebagai berikut :

Jika $X^{2}$ hitung $\leq X^{2}$ tabel maka distribusi normal dan sebaliknya jika $X^{2}$ hitung $\geq X_{\text {tabel }}^{2}$ maka distribusi data tidak normal. Berdasarkan hasil perhitungan uji normalitas posttest Model Pembelajaran Inquiry (variabel $X)$ memiliki $X^{2}$ hitung $=3,8236$, sedangkan perhitungan uji normalitas posttest Model Pembelajaran Number Head Together (variabel Y) memiliki $\mathrm{Y}^{2}{ }_{\text {hitung }}=$ 8,0426. Dari hasil tersebut, ternyata variabel $\mathrm{X}$ maupun variabel $\mathrm{Y}$ memiliki nilai $\mathrm{X}^{2}{ }_{\text {hitung }}$ lebih kecil dari nilai $\mathrm{X}_{\text {tabel. }}^{2}$ Maka dapat disimpulkan, data pada variabel $\mathrm{X}$ dan data variabel Y dinyatakan berdistribusi normal.

b. Uji Homogenitas

Perhitungan Uji homogenitas dilakukan dengan cara membandingkan nilai $\mathrm{F}_{\text {hitung }}$ dengan $\mathrm{F}_{\text {tabel }}$ pada taraf signifikansi $\alpha=$ 0,05 dan $\mathrm{dk}_{\text {pembilang }}=\mathrm{n}_{\mathrm{a}}-1$ dan $\mathrm{dk}_{\text {penyebut }}=$ $\mathrm{n}_{\mathrm{b}}$-1. apabila $\mathrm{F}_{\text {hitung }} \leq \mathrm{F}_{\text {tabel}}$, maka kedua kelompok data tersebut memiliki varian yang sama atau homogen.

Hasil hitung menunjukkan $\mathrm{F}_{\text {hitung }}=$ 1,09. Selanjutnya nilai $F_{\text {hitung }}$ dibandingkan dengan nilai $F_{\text {tabel }}$ untuk $\alpha=0,05$ dan $\mathrm{dk}_{\text {pembilang }}=30$ dan $\mathrm{dk}_{\text {penyebut }}=30$ diperoleh nilai $F_{\text {tabel }}=4,17$ Ternyata nilai $F_{\text {hitung }} \leq F_{\text {tabel }}$ $(1,09 \leq 4,17$. Maka dapat disimpulkan kedua kelompok data memiliki varian yang sama atau homogen.

\section{c. Uji Hipotesis Data}

Tabel 4.25 Perbedaan Antara Hasil Belajar Siswa yang Menggunakan model pembelajaran Inquiry dan model pembelajaran Numbered Heads together (NHT) Hasil Posttest

\begin{tabular}{ccccccc}
\hline No & $\mathbf{X}$ & $\mathbf{Y}$ & $\mathbf{X}$ & $\mathbf{x}^{2}$ & $\mathbf{Y}$ & $\mathbf{y}^{2}$ \\
\hline 1 & 80 & 75 & -2 & 6400 & 6 & 5625
\end{tabular}




\begin{tabular}{|c|c|c|c|c|c|c|}
\hline 2 & 100 & 80 & 18 & 10000 & 11 & 6400 \\
\hline 3 & 80 & 90 & -2 & 6400 & 21 & 8100 \\
\hline 4 & 95 & 70 & 13 & 9025 & 1 & 4900 \\
\hline 5 & 75 & 65 & -7 & 5625 & -4 & 4225 \\
\hline 6 & 90 & 50 & 8 & 8100 & -19 & 2500 \\
\hline 7 & 70 & 80 & -12 & 4900 & 11 & 6400 \\
\hline 8 & 90 & 75 & 8 & 8100 & 6 & 5624 \\
\hline 9 & 75 & 50 & -7 & 5625 & -19 & 2500 \\
\hline 10 & 100 & 80 & 18 & 10000 & 11 & 6400 \\
\hline 11 & 70 & 80 & -12 & 4900 & 11 & 6400 \\
\hline 12 & 90 & 60 & 8 & 8100 & -9 & 3600 \\
\hline 13 & 70 & 55 & -12 & 4900 & -14 & 3025 \\
\hline 14 & 75 & 85 & -7 & 5625 & 16 & 7225 \\
\hline 15 & 95 & 75 & 13 & 9025 & 6 & 5625 \\
\hline 16 & 80 & 60 & -2 & 6400 & -9 & 3600 \\
\hline 17 & 90 & 70 & 8 & 8100 & 1 & 4900 \\
\hline 18 & 65 & 50 & -17 & 4225 & -19 & 2500 \\
\hline 19 & 80 & 85 & -2 & 6400 & 16 & 7225 \\
\hline 20 & 100 & 60 & 18 & 10000 & -9 & 3600 \\
\hline 21 & 60 & 55 & -22 & 3600 & -14 & 3025 \\
\hline 22 & 70 & 80 & -12 & 4900 & 11 & 6400 \\
\hline 23 & 90 & 70 & 8 & 8100 & 1 & 4900 \\
\hline 24 & 70 & 55 & -12 & 4900 & -14 & 3025 \\
\hline 25 & 80 & 60 & -2 & 6400 & -9 & 3600 \\
\hline 26 & 75 & 85 & -7 & 5625 & 16 & 7225 \\
\hline 27 & 90 & 75 & 8 & 8100 & 6 & 5625 \\
\hline 28 & 85 & 70 & 3 & 7225 & 1 & 4900 \\
\hline 29 & 90 & 65 & 8 & 8100 & -4 & 4225 \\
\hline 30 & 85 & 85 & 3 & 7225 & 16 & 7225 \\
\hline 31 & 90 & 70 & 8 & 8100 & 1 & 4900 \\
\hline$\Sigma$ & 2555 & 2165 & & 214125 & & 155425 \\
\hline
\end{tabular}

Berdasarkan tabel di atas, maka langkah selanjutnya data tersebut dimasukkan ke dalam rumus perhitungan test " $t$ ", dengan langkah awal yaitu mencari mean $\mathrm{x}$ - dan $\mathrm{y}$.

Adapun perhitungannya adalah sebagai berikut:

1. Mencari mean $x$ dan $y$

a. Mencari mean variabel $\mathrm{x}$

$$
\text { Mean } X_{1}=\frac{\sum F x}{N}=\frac{2555}{31}=82,4149
$$

b. Mencari mean variabel y
Mean $\mathrm{X}_{2}=\frac{\sum F y}{N}=\frac{2165}{31}=69,8387$

2. Mencari standar deviasi nilai variabel $\mathrm{x}$ dan variabel y

a. Mencari standar deviasi nilai variabel $\mathrm{x}$

$\mathrm{SD}=\sqrt{\frac{\sum x^{2}}{N}}=\sqrt{\frac{3549}{31}}=\sqrt{114,418}=$ 10,86822

b. Mencari standar deviasi nilai variabel y

$\mathrm{SD}=\sqrt{\frac{\sum y^{2}}{N}}=\sqrt{\frac{4246}{31}}=\sqrt{136,96}=$

\section{1,86619}

3. Mencari varian variabel $\mathrm{X}$ dan $\mathrm{Y}$

a. Mencari varian hasil belajar IPA siswa kelas V A yang menggunakan Model Inquiry (variabel $\mathrm{X}$ )

$$
\begin{aligned}
& S_{1}^{2}=\frac{N \sum X^{2}-\left(\sum X\right)^{2}}{n(n-1)}=\frac{31(214125)-(2555)^{2}}{31(30)}= \\
& \frac{6637875-6528025}{31(30)}=\frac{109850}{930}=118,11 \\
& S_{1}=\sqrt{118,11}=10,86
\end{aligned}
$$

b. Mencari varian hasil belajar IPA siswa kelas V B yang menggunakan Model NHT (variabel $Y$ )

$S_{2}^{2}=\frac{N \sum Y^{2}-\left(\sum Y\right)^{2}}{n(n-1)}=\frac{31(155425)-(2165)^{2}}{31(30)}=$ $\frac{4818125-4687225}{31(30)}=\frac{130950}{930}=140,8064$

$s_{2}=\sqrt{140,8064}=11,86$

4. Mencari interpretasi terhadap t

$$
\begin{aligned}
& t=\frac{\overline{X_{1}}-\overline{X_{2}}}{\sqrt{\frac{s_{1}^{2}}{n_{1}}+\frac{s_{2}^{2}}{n_{2}}}}=\frac{82,4194-69,8387}{\sqrt{\frac{118,1}{31}+\frac{140,8}{31}}}=\frac{12,5762}{\sqrt{\frac{258,9}{31}}}= \\
& \frac{12,5762}{\sqrt{8,35161}}=\frac{12,5762}{2,8899}=4,352
\end{aligned}
$$

Sebelum dikonsultasikan dengan $t_{\text {tabel }}$ ditentukan dahulu df atau $\mathrm{db}=\left(\mathrm{N}_{1}+\mathrm{N}_{2}\right)-2$ $=(31+31)-2=62-2=60$. Berdasarkan perhitungan diatas, apabila dikonsultasikan dengan $t_{\text {tabel }}$ dengan df 60 pada taraf signifikan 5\% yaitu 2,000. Dengan demikian $t_{\text {hitung }}>\mathrm{t}_{\text {tabel }}(4,352>2,000)$, peneliti menganalisis menggunakan spss dan di peroleh $t_{\text {hitung }}>t_{\text {tabel }}(4,353>2,000)$ berarti hipotesis kerja $\left(\mathrm{H}_{\mathrm{a}}\right)$ dalam penelitian ini journal homepage : http://journal.univetbantara.ac.id/index.php/JBL/ 
diterima, yaitu hasil belajar IPA siswa kelas 5 yang diajarkan dengan menggunakan Model Pembelajaran Inquiry lebih baik dari pada siswa yang diajarkan dengan menggunakan Model Pembelajaran Number Head Together di SD Negeri 58 Kota Bengkulu. Sedangkan $\mathrm{H}_{\mathrm{o}}$ ditolak, hasil belajar IPA siswa kelas 5 yang diajarkan dengan menggunakan Model Pembelajaran Inquiry tidak lebih baik dari pada siswa yang diajarkan dengan menggunakan Model Pembelajaran Number Head Together di SD Negeri 58 Kota Bengkulu.

\section{PEMBAHASAN}

Penelitian ini menggunakan metode eksperimen, yakni menempatkan subjek penelitian kedalam dua kelompok yang dibedakan menjadi kategori kelas eksperimen yaitu dengan Model Pembelajaran Inquiry dan kelompok kontrol yaitu Model Pembelajaran Number Head Together. Dari hasil tes yang telah dilakukan diperoleh hasil sebagai berikut:

1. Dari 31 siswa kelas V yang diajar dengan Model Pembelajaran Inquiry nilai hasil belajar IPA yaitu (93\%) dengan rata-rata 93.

2. Dari 31 siswa kelas V yang diajar dengan Model Pembelajaran Number Head Together nilai hasil belajar IPA yaitu (81 $\%$ ) dengan rata-rata 81 .

3. Selanjutnya untuk menguji hipotesis kerja yang penulis diajukan dalam penelitian yaitu terdapat hasil belajar IPA dengan Model Pembelajaran Inquiry lebih baik dari pada Number Head Together pada siswa kelas V SD Negeri 66 Kota Bengkulu akan digunakan rumus " $\mathrm{t}$ " test maka $\mathrm{H}_{\mathrm{a}}$ diterima dan $\mathrm{H}_{\mathrm{o}}$ ditolak. Sehingga hipotesis kerja yang penulis ajukan tentang terdapat hasil belajar IPA dengan
Model Pembelajaran Inquiry lebih baik dari pada Number Head Together dengan nilai $(93 \%>81 \%)$ pada siswa kelas V SD Negeri 66 Kota Bengkulu dapat diterima dan berguna untuk semuanya.

\section{KESIMPULAN}

Berdasarkan hasil penelitian yang penulis lakukan dapat disimpulkan bahwa terdapat perbedaan hasil belajar antara penggunaan Model Pembelajaran Inquiry dan Number Head Together terhadap hasil belajar siswa kelas 5 SD Negeri 58 Kota Bengkulu. Dapat dilihat dari hasil hipotesis dengan menggunakan uji " $\mathrm{t}$ " terhadap kedua kelompok dengan hasil yang diperoleh, thitung $=4,352$ sedangkan $t_{\text {tabel }}$ dengan df 60 pada taraf signifikan $5 \%$ yaitu 2,000. Demikian $t_{\text {hitung }}>t_{\text {tabel }}(4,352>2,000)$ yang berarti hipotesis kerja $\left(\mathrm{H}_{\mathrm{a}}\right)$ dalam penelitian ini diterima, yaitu hasil belajar IPA siswa kelas 5 yang di ajarkan dengan menggunakan Model Pembelajaran Inquiry lebih baik dari pada siswa yang diajarkan dengan menggunakan Model Pembelajaran Number Head Together di SD Negeri 58 Kota Bengkulu. Dibuktikan dengan nilai rata-rata hasil belajar IPA Posttest kelas 5A lebih tinggi dibandingkan kelas 5B, yaitu Posstest 93\% > Posstest $81 \%$

\section{DAFTAR PUSTAKA}

Anwar, D. 2016. Kamus Besar Bahasa Indonesia. Surabaya: Amelia.

Asiyah, A. (2019). Improving organizational behavior for teachers and education resources. Jurnal Pendidikan" Edukasia Multikultura", 1(1).

Asiyah, A., Walid, A., \& Kusumah, R. G. T. (2019). Pengaruh Rasa Percaya Diri Terhadap Motivasi Berprestasi Siswa pada Mata Pelajaran IPA. Scholaria: Jurnal Pendidikan dan Kebudayaan, 9(3), 217-226. 
Baharuddin dan Wahyuni, N. 2018. Teori Belajar Dan Pembelajaran. Jogjakarta: AR-RUZZ Media Group.

Bektiningsih, B. (2020). Peningkatan Prestasi Belajar IPA Melalui Model Discovery Learning pada Siswa SD Negeri Gentan 01 Sukoharjo. Journal of Biology Learning, 2(1).

Dali, Z. (2018). Pancasila: Local Indigenous Islamic Character Education In Indonesia. MADANIA: JURNAL KAJIAN KEISLAMAN, 22(2), 185194.

Departemen Agama RI. 2020. Al-qur'an dan terjemahannya. Bandung: CV Penerbit Diponegoro.

Dimyanti dan Mudjiono. 2016. Belajar dan Pembelajaran. Jakarta: Rineka Cipta.

Maunah, B. 2019. Ilmu pendidikan. Yogyakarta: Teras.

Ngalimun. 2012. Strategi dan Model Pembelajaran. Yogyakarta: Aswaja Pressindo.

Pidarta, M. 2017. Perpustakaan Nasional RI:Katalog Dalam Terbitkan. Jakarta: PT Asdi Mahasatya.

Susanto, A. 2013. Teori Belajar Dan Pembelajaran Di Sekolah Dasar. Jakarta: Prenadamedia Group.

Tadjuddin, N. (2020). Emotional Intelligence of Elementary Scholar: Instructional Strategy and Personality Tendency. European Journal of Educational Research, 9(1), 203-213.

Walid, A., Sajidan, S., Ramli, M., \& Kusumah, R. G. T. (2019). Construction of the assessment concept to measure students' high order thinking skills. Journal for the Education of Gifted Young Scientists, 7(2), 237-251. 